\title{
Molecular Mechanism of Quorum-Sensing in Enterococcus faecalis: Its Role in Virulence and Therapeutic Approaches
}

\author{
Liaqat Ali ${ }^{1,2,3}$, Mohsan Ullah Goraya ${ }^{1,2}$, Yasir Arafat ${ }^{2}$, Muhammad Ajmal ${ }^{3}$, Ji-Long Chen ${ }^{1,4}$ \\ and Daojin $\mathrm{Yu}^{1}$,* \\ 1 College of Animal Sciences, Fujian Agriculture and Forestry University, Fuzhou 350002, China; \\ liaqatpaksw@yahoo.com (L.A.); goraya_uaf@yahoo.com (M.U.G.); chenjl@im.ac.cn (J.-L.C.) \\ 2 College of Life Sciences, Fujian Agriculture and Forestry University, Fuzhou 350002, China; \\ arafat_pep@yahoo.com \\ 3 Department of Biosciences, Faculty of Science, COMSATS Institute of Information Technology, \\ Islamabad 45550, Pakistan; muhammad.ajmal@comsats.edu.pk \\ 4 CAS Key Laboratory of Pathogenic Microbiology and Immunology, Institute of Microbiology, \\ Chinese Academy of Sciences (CAS), Beijing 100101, China \\ * Correspondence: yudaojin@yeah.net; Tel.: +86-591-8378-9486
}

Academic Editor: Guido R. M. M. Haenen

Received: 2 April 2017; Accepted: 26 April 2017; Published: 3 May 2017

\begin{abstract}
Quorum-sensing systems control major virulence determinants in Enterococcus faecalis, which causes nosocomial infections. The E. faecalis quorum-sensing systems include several virulence factors that are regulated by the cytolysin operon, which encodes the cytolysin toxin. In addition, the E. faecalis Fsr regulator system controls the expression of gelatinase, serine protease, and enterocin O16. The cytolysin and Fsr virulence factor systems are linked to enterococcal diseases that affect the health of humans and other host models. Therefore, there is substantial interest in understanding and targeting these regulatory pathways to develop novel therapies for enterococcal infection control. Quorum-sensing inhibitors could be potential therapeutic agents for attenuating the pathogenic effects of E. faecalis. Here, we discuss the regulation of cytolysin, the LuxS system, and the Fsr system, their role in E. faecalis-mediated infections, and possible therapeutic approaches to prevent E. faecalis infection.
\end{abstract}

Keywords: cytolysin; Enterococcus faecalis; Fsr; multidrug-resistant pathogen; quorum-sensing; quorum-sensing inhibitor; virulence factor

\section{Introduction}

Enterococcus faecalis is an aerotolerant, Gram-positive bacteria that is distributed widely in the natural environment, and in the gastrointestinal tracts of humans, animals, and insects. Among different enterococcal species, E. faecalis causes urinary tract infections, bacteremia, prosthetic joint infection, abdominal-pelvic infections, and endocarditis [1,2]. The most important features of E. faecalis are their high adaptability under harsh environmental conditions and their potential development of antibiotic resistance [3-5].

Antibiotic treatment eliminates vulnerable bacteria from the bacterial population, leaving resistant bacteria to grow and multiply. In E. faecalis, acquired elements, including antibiotic resistance genes, are estimated to represent over $25 \%$ of its genome [6]. Acquired and intrinsic resistance mean that E. faecalis shows resistance to a variety of antibiotics [4]. Virulence-specific therapeutics could avoid the selective pressure posed by antibiotics. Therefore, alternative anti-virulence therapeutic strategies, such as inhibition of quorum-sensing systems, could be sought to target this opportunistic pathogen. 
The quorum-sensing system is the population density-dependent regulatory mechanism by which bacteria communicate via signaling molecules, called autoinducers [7]. Generally, in quorum-sensing, bacteria produce autoinducers, and these molecules accumulate in the environment with the increase in the cell density. The role of these autoinducers depends on the location of their receptors, which are present on cell surface or in the cytoplasm. An autoinducer activates its cognate receptor specifically, which then activates the transcription of quorum-sensing genes [8]. This phenomenon provides a mechanism for bacteria to synchronize their social behavior, to communicate among themselves, and to regulate gene expression in response to their population density. Gram-positive bacteria contain another type of quorum-sensing, in which autoinducers are transported back into the bacterial cytoplasm, where they interact with a specific transcription factor, thereby regulating gene expression [8].

With the advent of proteomic studies in bacteria, it is revealed that the quorum-sensing system not only regulates their specific regulon but also control the expression of many other proteins ranging from surface proteins, transcription factors, virulence, biofilm formation to metabolic pathways [9-11]. Proteomics allow a comprehensive understanding of quorum-sensing phenomena and make it possible to better discern patterns of proteins expression in bacteria. It is estimated that over $23 \%$ of bacterial proteome can be regulated by quorum signaling [12]. Shao et al. have used the proteomic technique of 2D-PAGE (two-dimensional polyacrylamide gel electrophoresis) and identified 15 differentially expressed quorum-sensing-dependent proteins in vancomycin-resistant E. faecalis [10]. Following its identification, quorum-sensing plays a basic role in biofilm development. Using a proteomic approach (2D-PAGE coupled with mass spectrometry), Piras and coworkers reported that quorum-sensing-related LuxS enzyme (also known as S-ribosylhomocysteine lyase) is highly secreted in multidrug-resistant bacteria [9]. These results demonstrate that multidrug-resistant phenotype can also participate in a variety of regulatory and metabolic functions at high cell densities as well as an increase in their respective autoinducer concentrations. Extensive studies are still required to explore the detailed interaction of quorum-sensing proteins and whole proteomic expressions.

In Gram-positive bacteria, autoinducers are modified oligopeptides that are exported out of the cell. Outside the cell, because of their higher concentrations, different autoinducers bind with membrane-bound histidine kinase receptors. Histidine kinase is initially autophosphorylated and then activates the response regulator, which in turn activates the quorum-sensing regulon [13]. Peptide autoinducers are used commonly by Gram-positive bacteria, and acyl-homoserine lactone is produced by Gram-negative bacteria. By contrast, autoinducer 2 (AI-2) molecules are used for intra- and inter-species communication in Gram-positive and negative bacteria [11,14]. Currently, the "SigMol" repository database contains 182 unique autoinducer molecules identified inprokaryotes [15].

In E. faecalis, there are several sex pheromone-responsive plasmids that encode bacteriocins, aggregation substances, and a broad range of antibiotic resistance determinants (reviewed in [16]). Some of them, for example pCF10, pAD1, pPD1, pOB1, and pAM373, encode pheromones (cCF10, cAD1, cPD1, cOB1, and cAM373, respectively). The pheromone peptides (autoinducers) are transported through the ATP-binding cassette transport system [17]. Accumulation of these autoinducers in the extracellular milieu is sensed by their corresponding recipients to regulate conjugation-related mating functions [18]. Furthermore, once a recipient acquires a plasmid, the donor cells secrete the pheromone inhibitor. These inhibitors then downregulate the conjugation genes in donor cells, which controls the transfer of genes throughout a population [19]. E. faecalis also uses a cyclic peptide molecule, known as gelatinase biosynthesis-activating pheromone (GBAP), and $\mathrm{CylL}_{\mathrm{s}}$, as autoinducers, which interact with their transmembrane receptors FsrC, and CylR1, respectively, during the quorum-sensing process $[20,21]$.

Understanding the mechanisms by which E. faecalis populations regulate their mutual behavior, and how these behaviors are linked with the switch between commensal and pathogenic states, deserve attention. The role of E. faecalis system regulator (Fsr), cytolysin, and LuxS quorum-sensing regulatory systems, and possible therapeutics approaches, are discussed in this review. The Fsr 
and cytolysin regulatory systems in E. faecalis regulate much of their pathogenicity and have been documented in several studies [22-26], while the role of the LuxS regulatory mechanism in E. faecalis is less certain $[10,27]$.

\section{Fsr Mediated Quorum-Sensing}

The fsr locus of E. faecalis encodes a two-component regulatory system that senses the cell density and regulates virulence $[25,28]$. The $f s r$ locus is $2.8 \mathrm{~kb}$ in size and comprises four genes: $f_{s} r A, f_{s r} B, f_{s r} D$, and $f_{s r C}[29]$. Four genes, gelE, sprE, ef1097, and ef1097b, are directly dependent on the Fsr system [30]. The $f_{s} r A$ gene encodes the FsrA protein, which belongs to the LytTR family of DNA-binding domains [31]. The binding of phosphorylated FsrA to LytTR-binding sites in the upstream region of ef1097, fsrB, and gelE suggested that FsrA is a response regulator of the Fsr system [31]. Notably, fsr A transcription is under the control of a constitutive promoter; therefore, it is independent of the Fsr quorum-sensing system [32]. The $f_{s} r B$ gene encodes a transmembrane protein, FsrB, which belongs to the accessory gene regulator protein B (AgrB) family. FsrB processes a propeptide, FsrD (encoded by $f_{s} r D$ ), to generate GBAP (a lactone ring containing a short cyclic peptide of 11 amino acid residues), which is further exported out of the cell [29] (Figure 1). The fourth gene, $f s r C$, encodes the transmembrane histidine protein kinase $\mathrm{FsrC}$, the sensor-transmitter of the $f s r$ operon [20].

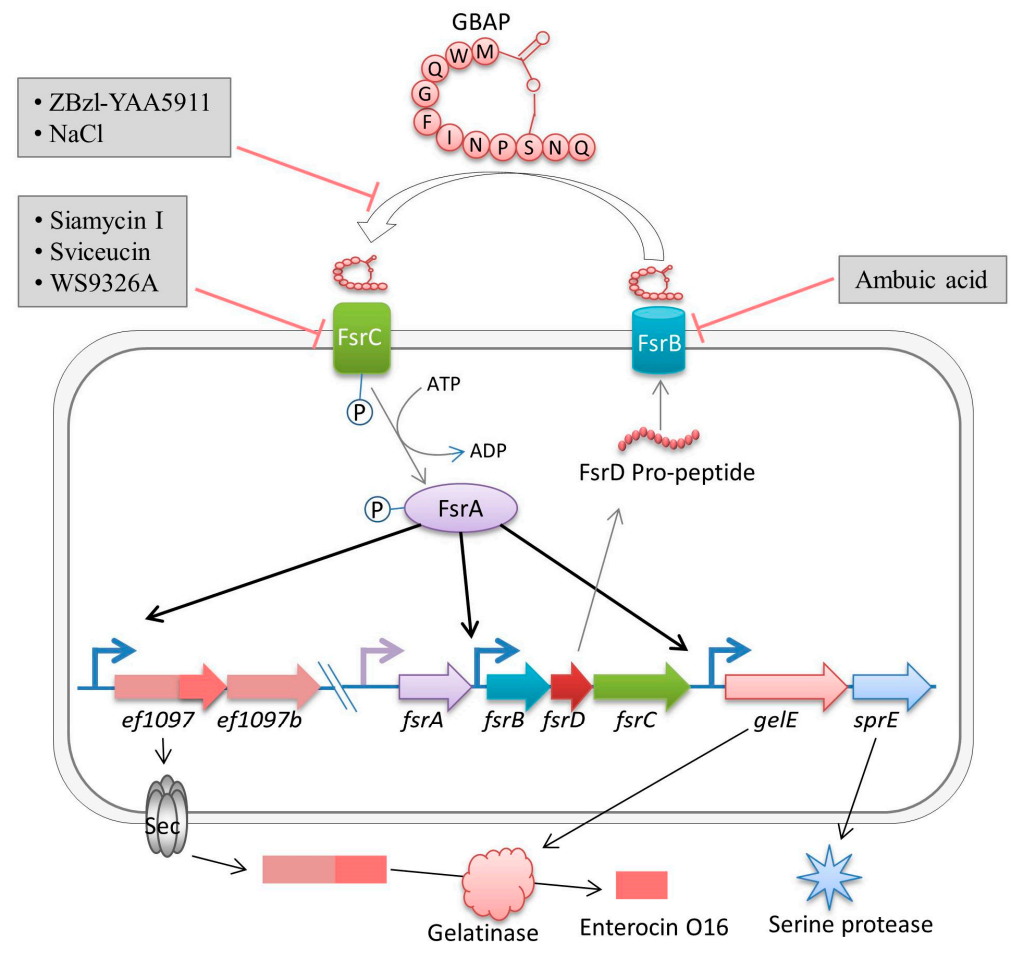

Figure 1. The Fsr quorum-sensing system and its regulation in E. faecalis. The FsrD propeptide (encoded by $f s r D$ ) is exported and processed to produce small lactone gelatinase biosynthesis-activating pheromone (GBAP) via FsrB. FsrC is part of a two-component regulatory system that responds to extracellular GBAP and phosphorylates the intracellular response regulator, FsrA, which then induces the expression of ef1097, ef1097b, fsr locus, gelE (encoding a gelatinase), and sprE (encoding a serine protease). The pre-proprotein (170 amino acids) encoded by ef1097 is cleaved (N-terminal 34 amino acids are removed) and transported through the Sec-dependent pathway, where gelatinase further trims the precursor to form enterocin O16 (68 C-terminal amino acids). ZBzl-YAA5911 (competitively) and $\mathrm{NaCl}$ (concentration-dependently) inhibit the interaction of GBAP with FsrC. Ambuic acid inhibits FsrB activity. Siamycin I, Sviceucin, and WS9326A inhibit the phosphorylation of FsrC. 
The fsr operon encodes a Staphylococcus aureus Agr (accessory gene regulator)-like system, which is a quorum-sensing system responsible for the regulation of virulence in the host tissues [13]. With the growth of an E. faecalis population, the concentration of GBAP rises in the external environment. Accumulation of GBAP in the extracellular milieu is sensed by FsrC, which is then phosphorylated to activate the response regulator FsrA [20]. Thus, this two-component regulatory system, consisting of FsrC (sensor) and FsrA (response regulator), responds to the accumulated GBAP, and is mainly involved in cell-cell communication in E. faecalis. Phosphorylated FsrA then regulates the transcription of $f s r B C D$, gelE-sprE operons, and ef1097 locus (ef1097 is located $800 \mathrm{~kb}$ upstream of the $f s r$ operon) [31]. Mutation of $f_{s} r A B C$ affected the downstream transcriptional response of gelE and $s p r E$ [25]. Therefore, $f s r A B C$ are essential for the regulatory functions of the fsr regulon [32]. Deletion of $f s r A, f s r B$, or $f s r C$ abolished the expressions of gelE and sprE completely; however, both were highly expressed in wild-type E. faecalis strain OG1RF [32]. Similarly, the expression of ef1097 was upregulated by 214 -fold in the late $\log$ phase and by 10 -fold in early stationary phase in E. faecalis OG1RF compared with the $f s r B$ mutant strain [33]. Interestingly, Dundar et al. identified enterocin O16 (also known as EntV and enterococcin V583), which is encoded by EntV gene (the ef1097 locus) [34-36]. The pre-proprotein encoded by ef1097 is translocated by the Sec system, and is further modified by an extracellular gelatinase [34]. Moreover, Sec system-mediated translocation and further modification of the large precursor pre-proprotein by gelatinase make it unclear whether or not enterocin O16 is a regular bacteriocin-type peptide. Nevertheless, E. faecalis is intrinsically resistant to enterocin O16, which indicates that the Fsr system also has antimicrobial and antifungal activity at higher cell densities [34,35]. However, additional studies are needed to investigate the structure and function of enterocin $\mathrm{O} 16$ in E. faecalis, and how the self-protective mechanism operates to protect E. faecalis from the harmful effects of enterocin O16. In addition to gelE, sprE, and ef1097, several genes are regulated indirectly by the Fsr system that have roles in surface adhesion, autolysis, and biofilm development $[30,33]$. However, the greater variability of genes regulated by $f s r$ suggests that this system is not only involved in virulence, but also alterations to metabolic activities, and biofilm-related components could play an important role.

\section{Pathogenesis of Fsr Mediated Quorum-Sensing}

Gelatinase and serine protease, encoded by gelE and $\operatorname{sprE}$, respectively, are regulated positively by the Fsr quorum-sensing system $[30,32,37]$. Both gelE and sprE are located adjacent to the $f s r$ genes, and are regulated by a common promoter [32] (Figure 1). Collectively, these proteases, and the Fsr quorum-sensing system, contribute to virulence, the degradation of host tissues, and biofilm formation [38-43].

The gelE gene encodes gelatinase, which is a mature polypeptide of 318 amino acid residues, with a molecular mass of about $34.5 \mathrm{kDa}$ [44]; 14 C-terminal amino acid residues are removed during processing to fully activate the protease activity of gelatinase [45]. Gelatinase has been classified as a metalloprotease II, capable of hydrolyzing gelatin; collagen; fibrin; fibrinogen; hemoglobin; complement components C3, C3a, and C5a; endothelin-1; casein; and other small peptides [44,46-48], which suggests its possible role in E. faecalis pathogenesis. Gelatinase activates the autolysin that is responsible for biofilm formation [43]. It also promotes E. faecalis in vitro translocation into the T84 human carcinoma cell line [49]. Moreover, gelatinase activates the protease-activated receptor-2 (PAR-2), which induced chronic intestinal inflammation in mice [50,51]. PAR-2 expression and serine protease activity have been observed in dogs with inflammatory bowel disease [52], which suggested that this receptor might be a risk factor for intestinal diseases mediated by the Fsr quorum-sensing system.

Among clinical E. faecalis isolates, the gelE gene was detectable in more than $78 \%$ of the isolates from urine, wounds, the genital tract, and blood [53]. Other studies noted that phenotypic gelatinase activity ranged from $13 \%$ to $70 \%$ of oral cavity isolates, which suggested their possible virulent role 
in the hospital environment [54,55]. In addition, indications of gelatinase-related virulence are also observed commonly in animals and insects $[30,37,56]$ (Table 1).

Table 1. The significant contributions of the E. faecalis quorum-sensing systems to virulence against humans and model organisms.

\begin{tabular}{|c|c|c|c|c|}
\hline $\begin{array}{l}\text { Associated } \\
\text { Disease }\end{array}$ & Host & Virulence Factors & Observed Activities & References \\
\hline Endocarditis & Human & Fsr system & $\begin{array}{l}\text { A higher prevalence of the } f s r \\
\text { locus in the endocarditis isolates } \\
(100 \%) \text { compared with fecal } \\
\text { isolates ( } 53 \%)\end{array}$ & [57] \\
\hline${ }^{1} \mathrm{IBD}$ & Human & Gelatinase & $\begin{array}{l}\text { The expression of gelE gene was } \\
\text { significantly higher in the IBD } \\
\text { patients compared with that in } \\
\text { the controls }\end{array}$ & [58] \\
\hline IBD & Mice & Gelatinase & $\begin{array}{l}\text { The gelE positive E. faecalis strain } \\
\text { induced a significantly higher } \\
\text { colitis and ileitis in the mice } \\
\text { compared with that of the gelE } \\
\text { mutant strains }\end{array}$ & [51] \\
\hline Peritonitis & Mice & $\begin{array}{l}\text { Cytolysin and } \\
\text { gelatinase }\end{array}$ & $\begin{array}{l}\text { Adding }^{2} \text { SRFE to the inoculum } \\
\text { considerably lowered the } \mathrm{LD}_{50} \text { for } \\
\text { E. faecalis OG1RF }\end{array}$ & [59] \\
\hline Systemic infection & $\begin{array}{l}\text { Mice and } \\
\text { G. mellonella }\end{array}$ & $\begin{array}{l}\text { Cytolysin and } \\
\text { gelatinase }\end{array}$ & $\begin{array}{l}\text { Injections of a gelE positive strain } \\
\text { cause death in the G. mellonella } \\
\text { larvae within } 8 \mathrm{~h} \text { and over } 2 \text { days } \\
\text { in mice. Meanwhile, cytolysin } \\
\text { was highly expressed in heart and } \\
\text { spleen of mice }\end{array}$ & [60] \\
\hline Ulcerative colitis & Mice & Gelatinase & $\begin{array}{l}\text { Gelatinase can regulate intestinal } \\
\text { permeability through }{ }^{3} \text { PAR2 }\end{array}$ & [50] \\
\hline Endophthalmitis & Rabbit & Fsr system & $\begin{array}{c}\text { An } f s r B \text { positive strain reduced } \\
\text { the B-wave amplitude } \\
\text { significantly compared with } \\
\text { an } f s r B \text { negative strain }\end{array}$ & [61] \\
\hline Endophthalmitis & Rabbit & $\begin{array}{l}\text { Gelatinase and } \\
\text { serine protease }\end{array}$ & $\begin{array}{l}100 \mathrm{CFU} / \mathrm{mL} \text { of } E \text {. faecalis OG1RF } \\
\text { caused significant loss of retinal } \\
\text { function after } 24 \text { h compared with } \\
\text { fsrB mutant strains }\end{array}$ & [62] \\
\hline Endocarditis & Rabbit & Gelatinase & $\begin{array}{l}\text { A gelE positive phenotype } \\
\text { increased bacterial burden in } \\
\text { the heart tissues }\end{array}$ & [48] \\
\hline Persistent infection & C. elegans & $\begin{array}{l}\text { Fsr system and } \\
\text { cytolysin }\end{array}$ & $\begin{array}{c}\text { Feeding on lawns containing } \\
\text { E. faecalis (cytolysin and } f s r B \\
\text { positive) caused a lethal infection }\end{array}$ & [39] \\
\hline Persistent infection & C. elegans & $\begin{array}{l}\text { Cytolysin and } \\
\text { gelatinase }\end{array}$ & $\begin{array}{l}\text { Ingestion of different strains of } \\
\text { E. faecalis having the } f s r \text { locus and } \\
\text { cytolysin operon significantly } \\
\text { increased its pathogenicity }\end{array}$ & [63] \\
\hline $\begin{array}{l}\text { Aerial tissue } \\
\text { damage }\end{array}$ & A. thaliana & Fsr system & $\begin{array}{l}\text { Parental strain OG1RF caused } \\
\text { mortality after } 7 \text { days } \\
\text { post-inoculation while } f \text { s } r B \text { and } \\
\text { sprE mutant strains significantly } \\
\text { attenuated virulence }\end{array}$ & [64] \\
\hline Systemic infection & D. melanogaster & $\begin{array}{l}\text { Gelatinase, serine } \\
\text { protease, and } \\
\text { enterocin O16 }\end{array}$ & $\begin{array}{l}\text { gelE, sprE, and ef1097 mutant } \\
\text { strains attenuated virulence } \\
\text { significantly compared with the } \\
\text { V583 parental strain }\end{array}$ & [30] \\
\hline
\end{tabular}


The $\operatorname{spr} E$ gene encodes a serine protease that has been characterized as a glutamyl endopeptidase I, with a mass of $25 \mathrm{kDa}$, and is a virulence factor of E. faecalis $[25,65]$. This protease contributes to pathogenesis in a variety of models, including animals [25,62,66], plants [64], and insects [30,39,41]. However, the exact mechanism of virulence in these hosts is poorly understood.

The role of the Fsr quorum-sensing system in virulence in vivo has been assessed in several experimental host models, including mice, rabbits, Caenorhabditis elegans, Arabidopsis thaliana, and Drosophila melanogaster (Table 1). In these experimental models, the activities of Fsr quorum-sensing were examined either by mutation (disruption or deletion in $f_{s} r A, f_{s} r B$, or $f_{s} r C$ ) or interference with GBAP-mediated quorum-sensing by various treatments. In 1998, Singh and coworkers used isogenic strains to evaluate the virulence effect of gelatinase in mice [59]. Their results indicated that inoculation $\left(8 \times 10^{8} \mathrm{CFU} / \mathrm{mL}\right)$ of gelE-defective mutant strain delayed mortality significantly compared with E. faecalis OG1RF. To further examine the delayed mortality, Qin et al. constructed insertion mutants of $f s r A, f s r B$, and $f s r C$, and downstream gene $s p r E$, to test the role of the Fsr quorum-sensing in virulence, using a mouse peritonitis model [25]. Based on their observations, gelE and sprE are Fsr quorum-sensing-mediated virulence factors in mouse peritonitis. Similarly, double mutants ( $\mathrm{gelE}$ and $s p r E$ ) in the $f s r A, f s r B$, and $f s r C$ mutant background showed more attenuated virulence compared with that of the gelE insertion mutant in a C. elegans infection model [41]. Moreover, double mutants (gelE and $s p r E$ ) or triple mutants $(f s r B, g e l E$ and $s p r E)$ displayed a more attenuated phenotype than the $f s r B$ mutant in a D. melanogaster model [30]. Collectively, these results indicated that, in addition to gelE and sprE, the Fsr quorum-sensing system, at a high cell density, might be regulated other virulence factors that play a significant role in the in vivo infection of $E$. faecalis.

Transcriptome analyses revealed that in addition to gelE, sprE, and ef1097, approximately 75 other genes are deregulated by $\geq 5$-fold by the Fsr system, including those related to surface proteins (EbpR), biofilm formation (BopD), and metabolic pathways [33]. In another study, Teixeira et al. found that the external addition of GBAP to $f s r B$ mutant strains upregulated the $\operatorname{lrg} A B$ genes [30]. These genes are responsible for murein hydrolase activity and are regulated by the lytSR operon in biofilm formation and extracellular DNA release [67]. In addition, gelatinase and serine protease are also involved in the regulation of an autolysin, $N$-acetylglucosaminidase (AtlA), which has a role in the fratricide and extracellular DNA release during biofilm formation [43]. Collectively, these studies suggested that bacteria with a deletion of gelE exhibited a tendency toward autolysis. By contrast, the deletion of $s p r E$ increased the fratricide activity, which suggested that the serine protease inhibited lysis of the cells [68]. Both gelatinase and serine protease control cell lysis by interacting with and changing the binding capacity of AtlA to the cell wall [43]. Moreover, gelatinase also cleaves a collagen adhesion protein (Ace, a bacterial protein), which affects E. faecalis's ability to adhere to collagen fibers. The activity of Ace, mediated by gelatinase, suggests a common role of the Fsr system in colonization or dissemination [69]. The Fsr quorum-sensing system and glycosyl transferases (GTFs, encoded by epaI and epaOX) promote biofilm formation [38]. GTFs might be involved in the synthesis and processing of cell wall polysaccharides, which sequester the antibiotics present in the vicinity of cell walls, thus prevent absorption of the antibiotics [38]. However, further studies are required to understand the exact mechanisms of Fsr's functions. Based on the studies mentioned above, it is speculated that there might be additional systems that play different roles in E. faecalis virulence, either directly or indirectly; however, they have yet to be identified. Understanding Fsr quorum-sensing would help to develop new and effective antivirulence drugs against $E$. faecalis pathogenesis.

\section{Cytolysin Regulation}

E. faecalis cytolysin is a pore-forming, Type-A lantibiotic [70], which has been classified more recently as a member of the two-component Class I lantibiotic enterocins (the bacteriocins produced by enterococci), which are post-translationally modified [71,72]. These two-component linear precursor peptides are encoded by two genes, $c y l L_{L}$ and $c y l L_{S}$, which are located in the cytolysin operon [23,73]. When the CylL $L_{S}$ concentration increases to a threshold level, it promotes the autoinduction of the 
cytolysin operon by a quorum-sensing mechanism [74]. The resulting toxicity of cytolysin has been observed in a wide range of organisms, including eukaryotes and prokaryotes $[5,24,26,39,74-77]$.

The cytolysin operon is located on the bacterial chromosome within the pathogenicity island, or on the pAD1 plasmid, and comprises eight genes [21,73,78] (Figure 2A). Two genes, cylR1 and cylR2, encode regulatory proteins, and are transcribed by a separate promoter $\left(P_{R}\right)$ and are thus transcribed divergently [21]. The remaining six genes $\left(c y l L_{L}, c y l L_{S}, c y l M, c y l B, c y l A\right.$, and $\left.c y l I\right)$ encode structural and functional proteins. Two structural genes, $c y l L_{L}$ and $c y l L_{S}$, encode a large subunit of 68 amino acids (a 30-residue leader peptide at the $\mathrm{N}$-terminus and a 38-residue core peptide at the C-terminus) and a small subunit of 63 amino acids (a 42-residue leader peptide at the N-terminus and a 21-residue core peptide at the C-terminus), respectively [75]. The products of the $c y l L_{L}$ and $c y l L_{S}$ genes are post-translationally modified by lanthionine synthetase (CylM). CylM dehydrates Thr and Ser residues in the core peptide to generate (Z)-2,3-didehydrobutyrine (Dhb) and 2,3-didehydroalanine (Dha), respectively [79]. The nucleophilic Michael-type addition reaction is then initiated by cysteine residues, resulting in the formation of thioether bonds between Dhb or Dha and nucleophilic cysteine side chains. Finally, this generates modified peptides containing methyllanthionine (starting from dehydrated Thr) or lanthionine (starting from dehydrated Ser) structures, which are both unusual amino acids in the peptides [77]. Intriguingly, Tang and van der Donk showed that one lanthionine bridge in CylL $L_{S}$ and two in CylL $_{L}$ exhibit an LL configuration, which is a uniquely different stereochemistry compared with previously characterized lantibiotics [80]. In addition, formation of the LL stereochemistry is substrate (CylL $L_{L}$ and $\left.C y l L_{S}\right)$-dependent, but not CylM-dependent [81]. CylM contains a dehydration domain that is involved in the hydrolysis of N-terminal amino acid residues of CylL $\mathrm{L}_{S}$ (three Thr and one Ser) to three Dhb and one Dha, respectively. In addition, the CylM C-terminal cyclization domain is thought to be responsible for the thioether crosslinks [82] (Figure 2B). Furthermore, CylB removes most of the $\mathrm{CylL}_{\mathrm{L}}$ and $\mathrm{CylL}_{\mathrm{S}}$ leader peptides and then transports them into the extracellular environment via an ATP-binding cassette transporter [83]. The cylA gene encodes a serine protease, CylA, which removes six amino acids (Gly-Asp-Val-Gln-Ala-Glu) from the N-terminus of the secreted toxin subunits, thus converting them to active toxin subunits on the cell surface [21,75]. However, these subunits form an inactive oligomeric complex in the presence of host cells; Cyl $\mathrm{L}_{\mathrm{L}}$ exhibits preferential binding to the host cell membrane, which allows free CylL $\mathrm{L}_{\mathrm{S}}$ to become signaling molecules [74]. Free CylL $\mathrm{L}_{\mathrm{S}}$ acts as an autoinducer, and at a certain threshold concentration, binds to the membrane-bound CylR1. This disrupts the interaction of the repressor protein (CylR2) with the operator sequence, which further leads to the expression of the cytolysin operon $[21,84]$. However, CylR1 signal transmission from extracellular CylL $L_{S}$ to intracellular CylR2 has not been completely determined. The final gene, cylI, encoding immunity protein CylI, is located immediately adjacent and downstream to the cylA [85]. In addition, CylI has been predicted to harbor a putative zinc binding metalloprotease motif and transmembrane domains [77]; however, the precise protective mechanism against the cytolysin toxicity involving Cyll has yet to be determined. 


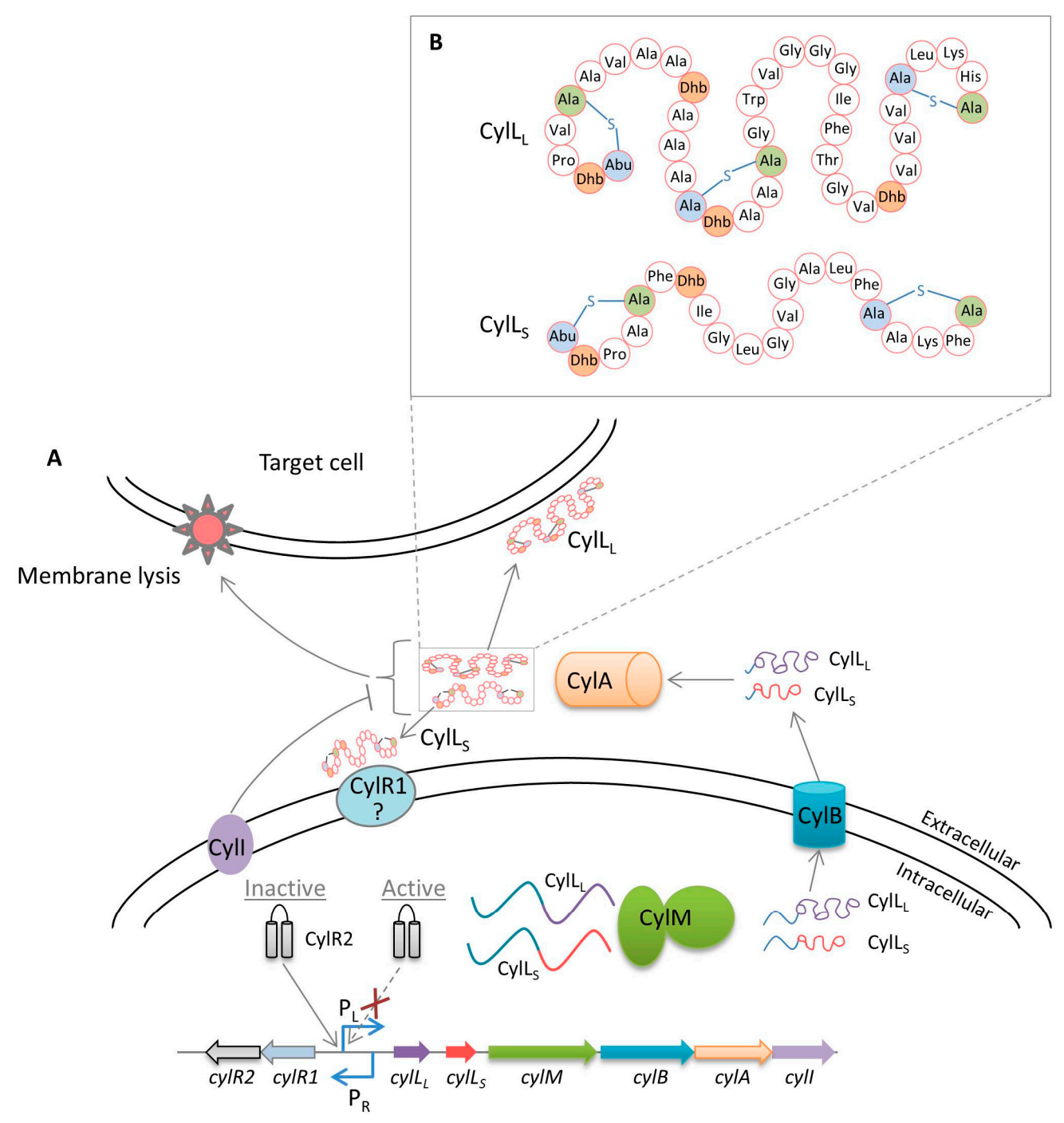

Figure 2. The cytolysin quorum-sensing system in E. faecalis. (A) The toxin structural components CylL $_{\mathrm{L}}$ (larger subunit) and CylL (smaller subunit) are encoded by $c y l L_{L}$ and $c y l L_{S}$. CylL $L_{L}$ and CylL $L_{S}$ core peptides are post-translationally modified by CylM, after which these peptides are further processed and transported by CylB. Extracellular protease, CylA, removes six amino acid residues (leader peptide) from both $\mathrm{CylL}_{\mathrm{L}}$ and $\mathrm{CylL}_{\mathrm{S}}$, making them active toxin subunits. The signal transduction mechanism linking the binding of extracellular CylL to CylR1 at the membrane with the dissociation of CylR2 from the $\mathrm{P}_{\mathrm{L}}$ promoter is currently unknown. Cyll provides self-immunity against cytolysin; (B) Structures of the CylL $L_{L}$ and CylL mature cytolysin subunits [82].

\section{Virulence of Cytolysin}

About $30 \%$ of the E. faecalis strains and $60 \%$ of clinical isolates are cytolysin producers [3,72]. The toxicity of $E$. faecalis cytolysin has been evaluated in vivo, in vitro, and for its clinical outcomes (Table 1). Cytolysin is active against a wide variety of Gram-positive bacteria, including clostridia, lactobacillales, and staphylococci $[86,87]$. The exact mode of action of cytolysin is unclear; however, its subunits, $\mathrm{CylL}_{\mathrm{L}}$ and $\mathrm{CylL}_{\mathrm{S}}$, bear some similarity to the well-studied bacteriocin lacticin 3147 [88], which is a pore-forming two-component (lacticin A1 and lacticin A2) lantibiotic, produced by Lactococcus lactis [89]. Pore-formation by lacticin 3147 takes place in three steps. First, the lacticin A1 subunit is associated with the membrane and lipid II. Secondly, its interactions with lacticin A2 form a high-affinity three-component complex. Finally, the C-terminus of lacticin A2 in the complex is 
translocated into the membrane to form a pore [90]. Whether the subunits of cytolysin interact in the same way, as well as their mechanism of action and spectrum of activity, has yet to be identified.

The cytolysin toxin can cause lysis of the human erythrocytes, polymorphonuclear leukocytes, retinal cells, and intestinal epithelial cells $[23,26,91]$, which suggested its causative role in hemolysis, endophthalmitis, compromised immunity, and intestinal diseases. The virulent behavior of cytolysin was also evident from a study in which mice were given intraperitoneal injection with strains harboring the cytolysin operon and isogenic non-cytolysin strains [92]. The cytolysin phenotype was observed to be potentially more virulent than the isogenic non-cytolysin strain in mice [92]. However, another study showed that an inoculum containing Sterile Rat Fecal Extracts (SREF) enhanced the severity of peritonitis in mice [59]. A retrospective study revealed that the cytolytic strains in enterococcal bacteremic infection resulted in a five-fold increase in the risk of mortality compared with the patients infected with non-cytolytic E. faecalis strains [93]. Bacteremia isolates have also been shown to have significantly higher levels of cytolysin than the endocarditis strains and strains in healthy individuals [94].

La Rosa et al. established a method of real-time monitoring of gelE- and cytolysin-promoter activity in Galleria mellonella larvae and mouse models [60]. They showed that the cytolysin and Fsr quorum-sensing systems were modulated by the host environmental conditions. E. faecalis strains that expressed either gelE or cytolysin induced mortality in C. elegans and G. mellonella infection models $[63,95]$. Whereas, combinations of gelE and cytolysin positive strains did not increase virulence significantly in both models $[63,95]$. This non-significant effect in the presence of both virulence traits might reflect either an antagonistic interaction or a saturation effect [63]. Gelatinase contributes to pathogenesis by triggering the proteolytic degradation of a wide range of host substrates [47,51], and is also implicated in the degradation of sex pheromone-related and other biologically active peptides [44]. In particular, the in vitro antagonistic effect of gelatinase significantly reduced the cytolysin activity of autoinducer CylLS [95]. However, the combined effect of gelatinase and cytolysin in vivo could be more severe [39]. Moreover, the underlying mechanism is important and should be explored further in vivo to devise therapeutic interventions against cytolysin virulence. Overall, after autoinduction of the cytolysin operon in the presence of a target cell membrane, cytolysin is involved in hemolysis, bacterial killing, endophthalmitis, endocarditis, and other virulence traits.

\section{Luxs System}

Many bacterial species, including E. faecalis, contain conserved $l u x S$ homologs, which produce the LuxS enzyme. The Pfs enzyme converts $S$-adenosylhomocysteine into S-ribosylhomocysteine and adenine, after which LuxS cleaves its substrate, $S$-ribosylhomocysteine, into homocysteine and 4,5-dihydroxy-2,3-pentanedione (DPD), which is the precursor of AI-2 [27]. The DPD molecules react with water and undergo cyclization to form AI-2 [96]. The synthesis of AI-2 has highlighted the potential role of the LuxS system in inter-species communication among in luxS containing bacteria at high cell density $[97,98]$. The LuxS system has been well studied in the Gram-negative, marine $\gamma$-proteobacterium Vibrio harveyi [27]. In V. harveyi, AI-2 is sensed by a periplasmic binding protein, LuxP [99]; however, bacteria lacking LuxP also respond to AI-2. Other receptors, such as LsrB (in Bacillus cereus, Escherichia coli, and Salmonella enterica) and RbsB (in Haemophilus influenza) have also been identified as potential receptors for AI-2 (reviewed in [100]). However, in most Gram-positive bacteria, including E. faecalis, AI-2 receptors have not yet been identified.

In E. faecalis, like other Gram-positive and Gram-negative bacteria, the LuxS enzyme is involved in the transcriptional regulation of a series of genes, including those involved in ATP generation, translation, cell wall/membrane biogenesis, and nucleotide transport and metabolism [10]. However, the mechanisms that induce the deregulation of genes implicated in these pathways, remain unclear. In addition, the LuxS system in E. faecalis also plays a role in biofilm formation in vitro $[10,101]$. It has been suggested that the deletion of luxS increases biofilm formation by E. faecalis and also increases bacterial cell-surface hydrophobicity, which suggest its role in biofilm formation [101]. 
The addition of exogenous AI-2 to a luxS mutant could solve this problem of whether biofilm formation is LuxS-dependent or metabolic, because $S$-adenosylhomocysteine hydrolase converts $S$-adenosylhomocysteine to homocysteine directly and thereby restores and maintains the methionine cycle, without the formation of the DPD [102]. The role of the AI-2 signaling molecule in biofilm formation and fratricide has also been reported in Streptococcus pneumoniae strains, which are closely related to the enterococci [103]. Therefore, the links among biofilm development, metabolic functions, fratricide, and the lack of known receptors for AI-2 pose the question of whether AI-2 signaling in E. faecalis has any role in intercellular communication. Based on the results of previous studies, it remains unclear whether in E. faecalis, the LuxS system only represents a general metabolic function or plays a role in quorum-sensing. The intercellular communication mechanism, overall significance in biofilm development, and the metabolic functions in E. faecalis are not well understood and should be investigated further.

\section{Therapeutic Approaches}

Enterococci have exhibited resistance to almost every antibiotic used against their infections [3]. Therefore, an alternative strategy, such as quorum-sensing disruption, is one of the most exciting areas in research into multidrug-resistant bacteria [104]. Interestingly, it has been reported that quorum-sensing inhibitors might enhance host immunity by rendering the pathogen avirulent, thus making them incapable of colonizing the host [105]. Initiatives have already been taken to target the Fsr and cytolysin quorum-sensing systems to develop anti-enterococcal therapeutic drugs [82,106-108] (Figure 3). Actinomycete secondary metabolites, such as siamycin I, inhibited FsrC of the Fsr system and stops biofilm formation at sublethal concentrations [109]. Later, Ma et al. showed that siamycin I inhibits autophosphorylation of the histidine kinase (FsrC) [110]. Similarly, sviceucin, a member of the type I lasso peptide family, inhibited the gelatinase activity at micromolar concentrations and possibly interacts with FsrC; however, this remains to be confirmed in detail [111]. Another promising study found that ambuic acid, a fungal secondary metabolite, inhibited the proteolytic modification of FsrD by binding to FsrB [112].

Continuous progress in the field of high-throughput screening has identified new quorum-sensing inhibitors. Two compounds, Y67-1 and Y67-2, were identified by high throughput screening analyses of actinomycetes culture extracts. These compounds were further characterized and evaluated as WS9326A and WS9326B, respectively, both of which are receptor antagonists of FsrC and lead to the inhibition of Fsr activity [114]. High concentrations of sodium chloride $(\geq 3 \%)$ have also been reported to repress the $f s r$ operon, thus abolishing biofilm formation $[115,116]$. Such inhibition might be caused by the activation of AtlA, which also contributes to biofilm development [43]. However, the precise mechanism by which sodium chloride inhibits gelatinase and GBAP production remains unclear.

In addition to natural inhibitors, synthetic inhibitors have also sparked increasing interest because of their specific antagonistic activity against the corresponding template peptides. Nakayama et al. synthesized a GBAP analog (ZBzl-YAA5911) and assessed its inhibition efficacy systematically [113]. Their results demonstrated that ZBzl-YAA5911 significantly reduced E. faecalis counts in endophthalmitis in aphakic rabbit eyes [113]. These findings identified ZBzl-YAA5911 as a promising inhibitor for the therapeutic development to cure endophthalmitis. Besides the Fsr system inhibitors, LuxS and cytolysin synthetic analogs are also equally important. Interestingly, Piras et al. have reported that the LuxS enzyme is upregulated in multidrug-resistant bacteria [9]. This finding indicates that the suppression of quorum-sensing regulatory genes may give new insights into the control of multi-antibiotic resistant pathogens. Similarly, the molecular structure of cytolysin synthetase could permit the design of strong binding inhibitors to prevent modification of the toxin subunits. The structure of Cyll is also important and might provide information regarding the interaction sites of synthetic inhibitors of cytolysin, and the immunity mechanism of E. faecalis at the molecular level. 


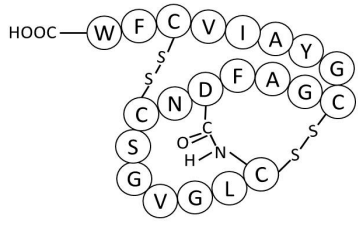

Siamycin I

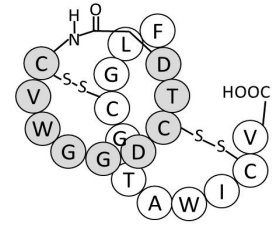

Sviceucin

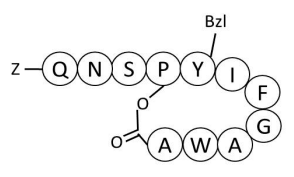

ZBZI-YAA5911
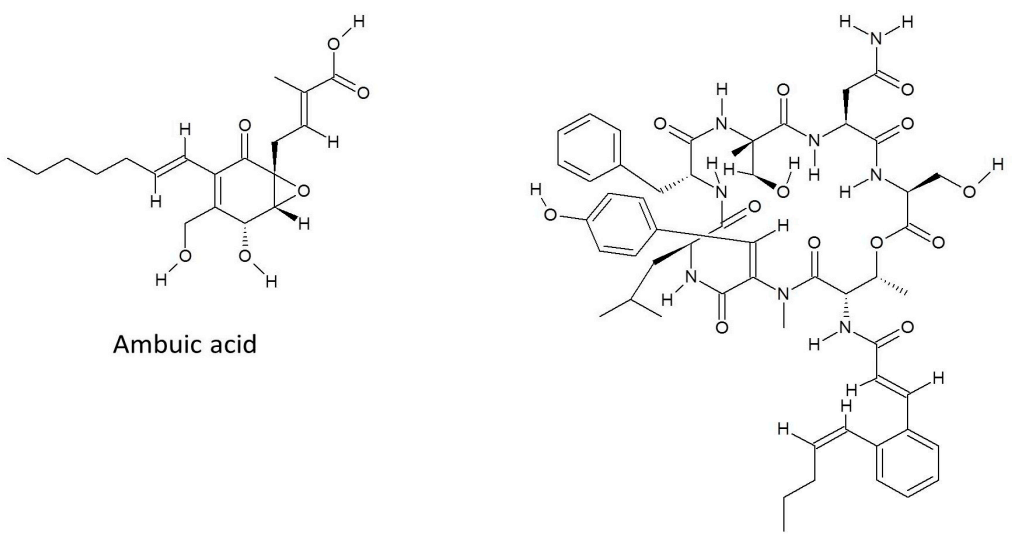

WS9326A

Figure 3. Structures of Fsr quorum-sensing system inhibitors: Siamycin $\mathrm{I}\left(\mathrm{IC}_{50}\right.$ approximately $\left.100 \mathrm{nM}\right)$ extracted from soil Streptomyces $s p$ [109]; Sviceucin obtained from Streptomyces sviceus, $(1$ and $10 \mu \mathrm{M}$ concentrations inhibited $50-70 \%$ and $>90 \%$ of gelatinase production, respectively) [111]; ZBzl-YAA5911 is a synthetic inhibitor with an $\mathrm{IC}_{50}$ of $26.2 \mathrm{nM}$ [113]; Ambuic acid ( $\mathrm{IC}_{50}$ approximately $\left.10 \mu \mathrm{M}\right)$, extracted from fungal secondary metabolites [112]; and WS9326A ( $\mathrm{IC}_{50}$ approximately $19 \mu \mathrm{M}$ ), extracted from a culture of actinomycetes [114].

\section{Perspectives}

To date, only two approaches, screening of natural and synthetic compounds, have been used to control the quorum-sensing mechanism in E. faecalis. These inhibitors (Figure 3) have been shown to be effective against the Fsr system. However, in vivo studies are important to understand the immune response, stability, toxicity, and metabolic pathways of quorum-sensing inhibitors. For example, siamycin I inhibits the growth of several Gram-positive bacteria and is involved in ATP-dependent enzyme activities [110]. Therefore, quorum-sensing inhibitors might also target other pathways or the normal microbiota [117]. Indeed, certain unknown factors might influence the activity of quorum-sensing inhibitors. However, the assessment of inhibitor activities in vivo, involving animal models of the disease, are very important to study immune response, as well as its detrimental effects. Ultimately, medical trials to check their effectiveness in humans are required. Furthermore, when developing new therapeutics against pathogenic E. faecalis, how commensal E. faecalis, which also releases pheromone-peptide COB1 that is capable of killing the pathogenic E. faecalis in the gastrointestinal tract, will be spared should be taken into account [118]. Therefore, transcriptomic and proteomic analyses of quorum-sensing inhibitors seems an elegant way to determine the mechanisms used by different inhibitors with respect to virulence and biofilm formation in the pathogenic bacteria [119-121].

It is also noteworthy that the quorum-sensing inhibitors might also be helpful to control virulence factors. The emergence of vancomycin-resistant E. faecalis, Fsr, and cytolysin quorum-sensing systems (the LuxS system remains under debate) pose a significant medical challenge. To realize a better therapeutic effect, there is a critical need to develop quorum-sensing inhibitors [104]. 
The three-dimensional structures of quorum-sensing regulating proteins offer molecular-level insights into strategies to treat $E$. faecalis quorum-sensing related virulence $[80,81,84,122]$. Furthermore, in vivo studies are needed to understand the disruption of the quorum-sensing mechanism by interfering with autoinducers during the course of infection in the host. Certainly, E. faecalis is likely to evade the host immune response by releasing quorum-sensing-related virulence factors [69].

\section{Conclusions}

Important virulence factors of E. faecalis are regulated by quorum-sensing circuits and pose a significant medical and environmental threat. For instance, E. faecalis is associated with different infections, including endocarditis, endophthalmitis, ulcerative colitis, and peritonitis. It is clear that the quorum-sensing regulatory proteins gelatinase, serine protease, enterocin $\mathrm{O} 16$, and cytolysin are key contributors to the pathogenesis of E. faecalis in several infection models. Thus, targeting E. faecalis quorum-sensing systems by focusing specifically on the autoinducers (GBAP and CylLS) and their receptors might lead to design of effective drugs against $E$. faecalis infections. Autoinducer-antagonists are expected to interact with specific receptors and do not exert selective pressure like antibiotics. This could be a promising strategy, in terms of specificity and lack of interference with the normal host flora. However, it is not possible to exclude the interference of autoinducer antagonists with the normal host flora.

Identification of natural products using high-throughput screening procedures and modern in silico techniques, such as molecular dynamics, has opened new horizons for future drug discovery. Furthermore, in vivo studies involving synthetic and natural inhibitors are needed to determine their effect on E. faecalis pathogenesis. The in vivo efficacy studies of the quorum-sensing inhibitors, broad scale clinical trials, and the analyses of the resulting positive as well as negative aspects, remain to be performed. However, various anti-virulence approaches and their possible interference with intercellular communication should be explored, as a feasible strategy for novel drug development.

Acknowledgments: This work was supported by the National Natural Science Foundation of China (grant numbers 31272606 and 31402217); the State Key Development Program during the 13th Five-Year Plan period (grant number 2016YFD0501310); and the Researching Center of Water Source and Water Safety, College of Resource and Environment, Fujian Agriculture and Forestry University, Fujian Province, China.

Author Contributions: Conception and design: Liaqat Ali and Daojin Yu. Drafting the manuscript: Liaqat Ali, Ji-Long Chen, Muhammad Ajmal, Yasir Arafat, and Daojin Yu. Critical revision of the article for important intellectual content: Liaqat Ali, Ji-Long Chen, Muhammad Ajmal, Mohsan Ullah Goraya, and Daojin Yu. Structure preparation with ChemSketch software: Yasir Arafat. Final approval: Liaqat Ali, Ji-Long Chen, Muhammad Ajmal, Mohsan Ullah Goraya, and Daojin Yu.

Conflicts of Interest: The authors declare no conflict of interest.

$\begin{array}{ll}\text { Abbreviations } & \\ \text { 2D-PAGE } & \text { Two-dimensional polyacrylamide gel electrophoresis } \\ \text { Agr } & \text { Accessory gene regulator } \\ \text { AI-2 } & \text { Autoinducer } 2 \\ \text { AtlA } & \text { N-acetylglucosaminidase } \\ \text { CFU } & \text { Colony forming units } \\ \text { DPD } & \text { 4,5-dihydroxy-2,3-pentanedione } \\ \text { Fsr } & \text { Faecalis system regulator } \\ \text { GBAP } & \text { Gelatinase biosynthesis activating pheromone } \\ \text { IBD } & \text { Inflammatory bowel diseases } \\ \text { PAR2 } & \text { Protease-activated receptor 2 } \\ \text { SRFE } & \text { Sterile rat fecal extracts }\end{array}$




\section{References}

1. Arias, C.A.; Contreras, G.A.; Murray, B.E. Management of multi-drug resistant enterococcal infections. Clin. Microbiol. Infect. 2010, 16, 555-562. [CrossRef] [PubMed]

2. Tornero, E.; Senneville, E.; Euba, G.; Petersdorf, S.; Rodriguez-Pardo, D.; Lakatos, B.; Ferrari, M.C.; Pilares, M.; Bahamonde, A.; Trebse, R.; et al. Characteristics of prosthetic joint infections due to Enterococcus sp. and predictors of failure: A multi-national study. Clin. Microbiol. Infect. 2014, 20, 1219-1224. [CrossRef] [PubMed]

3. Arias, C.A.; Murray, B.E. The rise of the Enterococcus: Beyond vancomycin resistance. Nat. Rev. Microbiol. 2012, 10, 266-278. [CrossRef] [PubMed]

4. Miller, W.R.; Munita, J.M.; Arias, C.A. Mechanisms of antibiotic resistance in enterococci. Expert Rev. Anti. Infect. Ther. 2014, 12, 1221-1236. [CrossRef] [PubMed]

5. Van Tyne, D.; Gilmore, M.S. Friend Turned Foe: Evolution of Enterococcal Virulence and Antibiotic Resistance. Annu. Rev. Microbiol. 2014, 337-356. [CrossRef] [PubMed]

6. Paulsen, I.T.; Banerjei, L.; Myers, G.S.A.; Nelson, K.E.; Seshadri, R.; Read, T.D.; Fouts, D.E.; Eisen, J.A.; Gill, S.R.; Heidelberg, J.F.; et al. Role of mobile DNA in the evolution of vancomycin-resistant Enterococcus Faecalis. Science 2003, 299, 2071-2074. [CrossRef] [PubMed]

7. Bassler, B.L.; Losick, R. Bacterially Speaking. Cell 2006, 125, 237-246. [CrossRef] [PubMed]

8. Rutherford, S.T.; Bassler, B.L. Bacterial quorum sensing: Its role in virulence and possibilities for its control. Cold Spring Harb. Perspect. Med. 2012, 2. [CrossRef] [PubMed]

9. Piras, C.; Soggiu, A.; Bonizzi, L.; Gaviraghi, A.; Deriu, F.; de Martino, L.; Iovane, G.; Amoresano, A.; Roncada, P. Comparative proteomics to evaluate multi drug resistance in Escherichia coli. Mol. Biosyst. 2012, 8, 1060-1067. [CrossRef] [PubMed]

10. Shao, C.; Shang, W.; Yang, Z.; Sun, Z.; Li, Y.; Guo, J.; Wang, X.; Zou, D.; Wang, S.; Lei, H.; et al. LuxS-dependent AI-2 regulates versatile functions in Enterococcus faecalis V583. J. Proteome Res. 2012, 11, 4465-4475. [CrossRef] [PubMed]

11. Di Cagno, R.; De Angelis, M.; Calasso, M.; Gobbetti, M. Proteomics of the bacterial cross-talk by quorum sensing. J. Proteom. 2011, 74, 19-34. [CrossRef] [PubMed]

12. Arevalo-Ferro, C.; Hentzer, M.; Reil, G.; Görg, A.; Kjelleberg, S.; Givskov, M.; Riedel, K.; Eberl, L. Identification of quorum-sensing regulated proteins in the opportunistic pathogen Pseudomonas aeruginosa by proteomics. Environ. Microbiol. 2003, 5, 1350-1369. [CrossRef] [PubMed]

13. Gray, B.; Hall, P.; Gresham, H. Targeting agr-and agr-Like quorum sensing systems for development of common therapeutics to treat multiple gram-positive bacterial infections. Sensors 2013, 13, 5130-5166. [CrossRef] [PubMed]

14. Miller, M.B.; Bassler, B.L. Quorum sensing in bacteria. Annu. Rev. Microbiol. 2001, 55, 165-199. [CrossRef] [PubMed]

15. Rajput, A.; Kaur, K.; Kumar, M. SigMol: Repertoire of quorum sensing signaling molecules in prokaryotes. Nucleic Acids Res. 2016, 44, D634-D639. [CrossRef] [PubMed]

16. Clewell, D.; Weaver, K.; Dunny, G.; Coque, T.; Francia, M.; Hayes, F. Extrachromosomal and Mobile Elements in Enterococci: Transmission, Maintenance, and Epidemiology. In Enterococci: From Commensals to Leading Causes of Drug Resistant Infection, 1st ed.; Gilmore, M.S., Clewell, D.B., Ike, Y., Shankar, N., Eds.; Massachusetts Eye and Ear Infirmary: Boston, MA, USA, 2014; pp. 225-305.

17. Varahan, S.; Harms, N.; Gilmore, M.S.; Tomich, J.M.; Hancock, L.E. An ABC transporter is required for secretion of peptide sex pheromones in Enterococcus faecalis. mBio 2014, 5. [CrossRef] [PubMed]

18. Dunny, G.M. Enterococcal sex pheromones: Signaling, social behavior, and evolution. Annu. Rev. Genet. 2013, 47, 457-482. [CrossRef] [PubMed]

19. Chatterjee, A.; Cook, L.C.C.; Shu, C.C.; Chen, Y.; Manias, D.A.; Ramkrishna, D.; Dunny, G.M.; Hu, W.S. Antagonistic self-sensing and mate-sensing signaling controls antibiotic-resistance transfer. Proc. Natl. Acad. Sci. USA 2013, 110, 7086-7090. [CrossRef] [PubMed]

20. Nakayama, J.; Cao, Y.; Horii, T.; Sakuda, S.; Akkermans, A.D.L.; De Vos, W.M.; Nagasawa, H. Gelatinase biosynthesis-activating pheromone: A peptide lactone that mediates a quorum sensing in Enterococcus faecalis. Mol. Microbiol. 2001, 41, 145-154. [CrossRef] [PubMed]

21. Haas, W.; Shepard, B.D.; Gilmore, M.S. Two-component regulator of Enterococcus faecalis cytolysin responds to quorum-sensing autoinduction. Nature 2002, 415, 84-87. [CrossRef] [PubMed] 
22. Cook, L.C.; Federle, M.J. Peptide pheromone signaling in Streptococcus and Enterococcus. FEMS Microbiol. Rev. 2014, 38, 473-492. [CrossRef] [PubMed]

23. Cox, C.R.; Coburn, P.S.; Gilmore, M.S. Enterococcal cytolysin: A novel two component peptide system that serves as a bacterial defense against eukaryotic and prokaryotic cells. Curr. Protein Pept. Sci. 2005, 6, 77-84. [CrossRef] [PubMed]

24. Garsin, D.A.; Frank, K.L.; Silanpaa, J.; Ausubel, F.M.; Hartke, A.; Shankar, N.; Murray, B.E. Pathogenesis and Models of Enterococcal Infection. In Enterococci: From Commensals to Leading Causes of Drug Resistant Infection, 1st ed.; Gilmore, M.S., Clewell, D.B., Ike, Y., Shankar, N., Eds.; Massachusetts Eye and Ear Infirmary: Boston, MA, USA, 2014; pp. 135-187.

25. Qin, X.; Singh, K.V.; Weinstock, G.M.; Murray, B.E. Effects of Enterococcus faecalis fsr genes on production of gelatinase and a serine protease and virulence. Infect. Immun. 2000, 68, 2579-2586. [CrossRef] [PubMed]

26. Van Tyne, D.; Martin, M.J.; Gilmore, M.S. Structure, function, and biology of the Enterococcus faecalis cytolysin. Toxins 2013, 5, 895-911. [CrossRef] [PubMed]

27. Schauder, S.; Bassler, B.L. The languages of bacteria. Genes Dev. 2001, 15, 1468-1480. [CrossRef] [PubMed]

28. Ji, G.; Beavis, R.; Novick, R.P. Bacterial interference caused by autoinducing peptide variants. Science 1997, 276, 2027-2030. [CrossRef] [PubMed]

29. Nakayama, J.; Chen, S.; Oyama, N.; Nishiguchi, K.; Azab, E.A.; Tanaka, E.; Kariyama, R.; Sonomoto, K. Revised model for Enterococcus faecalis fsr quorum-sensing system: The small open reading frame $f s r D$ encodes the gelatinase biosynthesis-activating pheromone propeptide corresponding to staphylococcal AgrD. J. Bacteriol. 2006, 188, 8321-8326. [CrossRef] [PubMed]

30. Teixeira, N.; Varahan, S.; Gorman, M.J.; Palmer, K.L.; Zaidman-Remy, A.; Yokohata, R.; Nakayama, J.; Hancock, L.E.; Jacinto, A.; Gilmore, M.S.; et al. Drosophila Host Model Reveals New Enterococcus faecalis Quorum-Sensing Associated Virulence Factors. PLoS ONE 2013, 8, e64740. [CrossRef] [PubMed]

31. Del Papa, M.F.; Perego, M. Enterococcus faecalis virulence regulator FsrA binding to target promoters. J. Bacteriol. 2011, 193, 1527-1532. [CrossRef] [PubMed]

32. Qin, X.; Singh, K.V.; Weinstock, G.M.; Murray, B.E. Characterization of $f s r$, a regulator controlling expression of gelatinase and serine protease in Enterococcus faecalis OG1RF. J. Bacteriol. 2001, 183, 3372-3382. [CrossRef] [PubMed]

33. Bourgogne, A.; Hilsenbeck, S.G.; Dunny, G.M.; Murray, B.E. Comparison of OG1RF and an isogenic $f s r B$ deletion mutant by transcriptional analysis: The Fsr system of Enterococcus faecalis is more than the activator of gelatinase and serine protease. J. Bacteriol. 2006, 188, 2875-2884. [CrossRef] [PubMed]

34. Dundar, H.; Brede, D.A.; La Rosa, S.L.; El-Gendy, A.O.; Diep, D.B.; Nes, I.F. The fsr Quorum-Sensing System and Cognate Gelatinase Orchestrate the Expression and Processing of Proprotein EF_1097 into the Mature Antimicrobial Peptide Enterocin O16. J. Bacteriol. 2015, 197, 2112-2121. [CrossRef] [PubMed]

35. Graham, C.E.; Cruz, M.R.; Garsin, D.A.; Lorenz, M.C. Enterococcus faecalis bacteriocin EntV inhibits hyphal morphogenesis, biofilm formation, and virulence of Candida albicans. Proc. Natl. Acad. Sci. USA 2017, 114, 4507-4512. [CrossRef] [PubMed]

36. Swe, P.M.; Heng, N.C.K.; Ting, Y.T.; Baird, H.J.; Carne, A.; Tauch, A.; Tagg, J.R.; Jack, R.W. ef1097 and ypkK encode enterococcin V583 and corynicin JK, members of a new family of antimicrobial proteins (bacteriocins) with modular structure from Gram-positive bacteria. Microbiology 2007, 153, 3218-3227. [CrossRef] [PubMed]

37. Gaspar, F.; Teixeira, N.; Rigottier-Gois, L.; Marujo, P.; Nielsen-LeRoux, C.; Crespo, M.T.B.; Lopes, M.; de, F.S.; Serror, P. Virulence of Enterococcus faecalis dairy strains in an insect model: The role of $f s r B$ and gelE. Microbiology 2009, 155, 3564-3571. [CrossRef] [PubMed]

38. Dale, J.L.; Cagnazzo, J.; Phan, C.Q.; Barnes, A.M.T.; Dunny, G.M. Multiple roles for Enterococcus faecalis glycosyltransferases in biofilm-associated antibiotic resistance, cell envelope integrity, and conjugative transfer. Antimicrob. Agents Chemother. 2015, 59, 4094-4105. [CrossRef] [PubMed]

39. Garsin, D.A.; Sifri, C.D.; Mylonakis, E.; Qin, X.; Singh, K.V.; Murray, B.E.; Calderwood, S.B.; Ausubel, F.M. A simple model host for identifying Gram-positive virulence factors. Proc. Natl. Acad. Sci. USA 2001, 98, 10892-10897. [CrossRef] [PubMed]

40. Hancock, L.E.; Perego, M. The Enterococcus faecalis fsr two-component system controls biofilm development through production of gelatinase. J. Bacteriol. 2004, 186, 5629-5639. [CrossRef] [PubMed] 
41. Sifri, C.D.; Mylonakis, E.; Singh, K.V.; Qin, X.; Garsin, D.A.; Murray, B.E.; Ausubel, F.M.; Calderwood, S.B. Virulence effect of Enterococcus faecalis protease genes and the quorum-sensing locus fsr in Caenorhabditis elegans and mice. Infect. Immun. 2002, 70, 5647-5650. [CrossRef] [PubMed]

42. Soares, R.O.; Fedi, A.C.; Reiter, K.C.; Caierão, J.; d'Azevedo, P.A. Correlation between biofilm formation and gelE, esp, and agg genes in Enterococcus spp. clinical isolates. Virulence 2014, 5, 634-637. [CrossRef] [PubMed]

43. Thomas, V.C.; Hiromasa, Y.; Harms, N.; Thurlow, L.; Tomich, J.; Hancock, L.E. A fratricidal mechanism is responsible for eDNA release and contributes to biofilm development of Enterococcus faecalis. Mol. Microbiol. 2009, 72, 1022-1036. [CrossRef] [PubMed]

44. Makinen, P.L.; Clewell, D.B.; An, F.; Makinen, K.K. Purification and substrate specificity of a strongly hydrophobic extracellular metalloendopeptidase ('gelatinase') from Streptococcus faecalis (strain 0G1-10). J. Biol. Chem. 1989, 264, 3325-3334. [PubMed]

45. Del Papa, M.F.; Hancock, L.E.; Thomas, V.C.; Perego, M. Full activation of Enterococcus faecalis gelatinase by a C-terminal proteolytic cleavage. J. Bacteriol. 2007, 189, 8835-8843. [CrossRef] [PubMed]

46. Gútiez, L.; Borrero, J.; Jiménez, J.J.; Gómez-Sala, B.; Recio, I.; Cintas, L.M.; Herranz, C.; Hernández, P.E. Genetic and biochemical evidence that recombinant Enterococcus spp. strains expressing gelatinase (GelE) produce bovine milk-derived hydrolysates with high angiotensin converting enzyme-inhibitory activity (ACE-IA). J. Agric. Food Chem. 2014, 62, 5555-5564. [CrossRef] [PubMed]

47. Park, S.Y.; Shin, Y.P.; Kim, C.H.; Park, H.J.; Seong, Y.S.; Kim, B.S.; Seo, S.J.; Lee, I.H. Immune evasion of Enterococcus faecalis by an extracellular gelatinase that cleaves C3 and iC3b. J. Immunol. 2008, 181, 6328-6336. [CrossRef] [PubMed]

48. Thurlow, L.R.; Thomas, V.C.; Narayanan, S.; Olson, S.; Fleming, S.D.; Hancock, L.E. Gelatinase contributes to the pathogenesis of endocarditis caused by Enterococcus faecalis. Infect. Immun. 2010, 78, 4936-4943. [CrossRef] [PubMed]

49. Zeng, J.; Teng, F.; Murray, B.E. Gelatinase is important for translocation of Enterococcus faecalis across polarized human enterocyte-like T84 cells. Infect. Immun. 2005, 73, 1606-1612. [CrossRef] [PubMed]

50. Maharshak, N.; Huh, E.Y.; Paiboonrungruang, C.; Shanahan, M.; Thurlow, L.; Herzog, J.; Djukic, Z.; Orlando, R.; Pawlinski, R.; Ellermann, M.; et al. Enterococcus faecalis gelatinase mediates intestinal permeability via Protease Activated Receptor 2. Infect. Immun. 2015, 83, 2762-2770. [CrossRef] [PubMed]

51. Steck, N.; Hoffmann, M.; Sava, I.G.; Kim, S.C.; Hahne, H.; Tonkonogy, S.L.; Mair, K.; Krueger, D.; Pruteanu, M.; Shanahan, F.; et al. Enterococcus faecalis metalloprotease compromises epithelial barrier and contributes to intestinal inflammation. Gastroenterology 2011, 141, 959-971. [CrossRef] [PubMed]

52. Maeda, S.; Ohno, K.; Uchida, K.; Igarashi, H.; Goto-Koshino, Y.; Fujino, Y.; Tsujimoto, H. Intestinal protease-activated receptor-2 and fecal serine protease activity are increased in canine inflammatory bowel disease and may contribute to intestinal cytokine expression. J. Vet. Med. Sci. 2014, 76, 1119-1127. [CrossRef] [PubMed]

53. Strateva, T.; Atanasova, D.; Savov, E.; Petrova, G.; Mitov, I. Incidence of virulence determinants in clinical Enterococcus faecalis and Enterococcus faecium isolates collected in Bulgaria. Braz. J. Infect. Dis. 2016, 20, 127-133. [CrossRef] [PubMed]

54. Anderson, A.C.; Jonas, D.; Huber, I.; Karygianni, L.; Wölber, J.; Hellwig, E.; Arweiler, N.; Vach, K.; Wittmer, A.; Al-Ahmad, A. Enterococcus faecalis from Food, Clinical Specimens, and Oral Sites: Prevalence of Virulence Factors in Association with Biofilm Formation. Front. Microbiol. 2015, 6, 1534. [CrossRef] [PubMed]

55. Zoletti, G.O.; Pereira, E.M.; Schuenck, R.P.; Teixeira, L.M.; Siqueira, J.F.; Dos Santos, K.R.N. Characterization of virulence factors and clonal diversity of Enterococcus faecalis isolates from treated dental root canals. Res. Microbiol. 2011, 162, 151-158. [CrossRef] [PubMed]

56. Hwang, I.Y.; Lim, S.K.; Ku, H.O.; Park, C.K.; Jung, S.C.; Park, Y.H.; Nam, H.M. Occurrence of virulence determinants in fecal Enterococcus faecalis isolated from pigs and chickens in Korea. J. Microbiol. Biotechnol. 2011, 21, 1352-1355. [CrossRef] [PubMed]

57. Pillai, S.K.; Sakoulas, G.; Gold, H.S.; Wennersten, C.; Eliopoulos, G.M.; Moellering, R.C.; Inouye, R.T. Prevalence of the Fsr locus in Enterococcus faecalis infections. J. Clin. Microbiol. 2002, 40, 2651-2652. [CrossRef] [PubMed]

58. Golińska, E.; Tomusiak, A.; Gosiewski, T.; Więcek, G.; Machul, A.; Mikołajczyk, D.; Bulanda, M.; Heczko, P.B.; Strus, M. Virulence factors of Enterococcus strains isolated from patients with inflammatory bowel disease. World J. Gastroenterol. 2013, 19, 3562-3572. [CrossRef] [PubMed] 
59. Singh, K.V.; Qin, X.; Weinstock, G.M.; Murray, B.E. Generation and testing of mutants of Enterococcus faecalis in a mouse peritonitis model. J. Infect. Dis. 1998, 178, 1416-1420. [CrossRef] [PubMed]

60. La Rosa, S.L.; Casey, P.G.; Hill, C.; Diep, D.B.; Nes, I.F.; Brede, D.A. In vivo assessment of growth and virulence gene expression during commensal and pathogenic lifestyles of luxABCDE tagged Enterococcus faecalis in murine gastro intestinal and intravenous infection models. Appl. Environ. Microbiol. 2013, 79, 3986-3997. [CrossRef] [PubMed]

61. Mylonakis, E.; Engelbert, M.; Qin, X.; Sifri, C.D.; Murray, B.E.; Ausubel, F.M.; Gilmore, M.S.; Calderwood, S.B. The Enterococcus faecalis $f_{s} r B$ gene, a key component of the fsr quorum-sensing system, is associated with virulence in the rabbit endophthalmitis model. Infect. Immun. 2002, 70, 4678-4681. [CrossRef] [PubMed]

62. Engelbert, M.; Mylonakis, E.; Ausubel, F.M.; Calderwood, S.B.; Gilmore, M.S. Contribution of gelatinase, serine protease, and $f_{s} r$ to the pathogenesis of Enterococcus faecalis endophthalmitis. Infect. Immun. 2004, 72, 3628-3633. [CrossRef] [PubMed]

63. La Rosa, S.L.; Snipen, L.G.; Murray, B.E.; Willems, R.J.L.; Gilmore, M.S.; Diep, D.B.; Nes, I.F.; Brede, D.A. A genomic virulence reference map of Enterococcus faecalis reveals an important contribution of phage03-like elements in nosocomial genetic lineages to pathogenicity in a Caenorhabditis elegans infection model. Infect. Immun. 2015, 83, 2156-2167. [CrossRef] [PubMed]

64. Jha, A.K.; Bais, H.P.; Vivanco, J.M. Enterococcus faecalis mammalian virulence-related factors exhibit potent pathogenicity in the Arabidopsis thaliana plant model. Infect. Immun. 2005, 73, 464-475. [CrossRef] [PubMed]

65. Kawalec, M.; Potempa, J.; Moon, J.L.; Travis, J.; Murray, B.E. Molecular diversity of a putative virulence factor: Purification and characterization of isoforms of an extracellular serine glutamyl endopeptidase of Enterococcus faecalis with different enzymatic activities. J. Bacteriol. 2005, 187, 266-275. [CrossRef] [PubMed]

66. Prajsnar, T.K.; Renshaw, S.A.; Ogryzko, N.V.; Foster, S.J.; Serror, P.; Mesnagea, S. Zebrafish as a novel vertebrate model to dissect enterococcal pathogenesis. Infect. Immun. 2013, 81, 4271-4279. [CrossRef] [PubMed]

67. Sharma-Kuinkel, B.K.; Mann, E.E.; Ahn, J.S.; Kuechenmeister, L.J.; Dunman, P.M.; Bayles, K.W. The Staphylococcus aureus LytSR two-component regulatory system affects biofilm formation. J. Bacteriol. 2009, 191, 4767-4775. [CrossRef] [PubMed]

68. Dunny, G.M.; Hancock, L.E.; Shankar, N. Enterococcal biofilm structure and role in colonization and disease. In Enterococci: From Commensals to Leading Causes of Drug Resistant Infection, 1st ed.; Gilmore, M.S., Clewell, D.B., Ike, Y., Shankar, N., Eds.; Massachusetts Eye and Ear Infirmary: Boston, MA, USA, 2014; pp. 400-423.

69. Pinkston, K.L.; Gao, P.; Diaz-Garcia, D.; Sillanpaa, J.; Nallapareddy, S.R.; Murray, B.E.; Harvey, B.R. The Fsr quorum-sensing system of Enterococcus faecalis modulates surface display of the collagen-binding MSCRAMM Ace through regulation of gelE. J. Bacteriol. 2011, 193, 4317-4325. [CrossRef] [PubMed]

70. Sahl, H.G.; Jack, R.W.; Bierbaum, G. Biosynthesis and biological activities of lantibiotics with unique post-translational modifications. Eur. J. Biochem. 1995, 230, 827-853. [CrossRef] [PubMed]

71. Franz, C.M.; Van Belkum, M.J.; Holzapfel, W.H.; Abriouel, H.; Gálvez, A. Diversity of enterococcal bacteriocins and their grouping in a new classification scheme. FEMS Microbiol. Rev. 2007, 31, $293-310$. [CrossRef] [PubMed]

72. Nes, I.F.; Diep, D.B.; Ike, Y. Enterococcal bacteriocins and antimicrobial proteins that contribute to niche control. In Enterococci: From Commensals to Leading Causes of Drug Resistant Infection, 1st ed.; Gilmore, M.S., Clewell, D.B., Ike, Y., Shankar, N., Eds.; Massachusetts Eye and Ear Infirmary: Boston, MA, USA, 2014; pp. 466-488.

73. Shankar, N.; Baghdayan, A.S.; Gilmore, M.S. Modulation of virulence within a pathogenicity island in vancomycin-resistant Enterococcus faecalis. Nature 2002, 417, 746-750. [CrossRef] [PubMed]

74. Coburn, P.S.; Pillar, C.M.; Jett, B.D.; Haas, W.; Gilmore, M.S. Enterococcus faecalis senses target cells and in response expresses cytolysin. Science 2004, 306, 2270-2272. [CrossRef] [PubMed]

75. Booth, M.C.; Bogie, C.P.; Sahl, H.G.; Siezen, R.J.; Hatter, K.L.; Gilmore, M.S. Structural analysis and proteolytic activation of Enterococcus faecalis cytolysin, a novel lantibiotic. Mol. Microbiol. 1996, 21, 1175-1184. [CrossRef] [PubMed]

76. Clewell, D.B. Bacterial sex pheromone-induced plasmid transfer. Cell 1993, 73, 9-12. [CrossRef]

77. Coburn, P.S.; Gilmore, M.S. The Enterococcus faecalis cytolysin: A novel toxin active against eukaryotic and prokaryotic cells. Cell. Microbiol. 2003, 5, 661-669. [CrossRef] [PubMed] 
78. Dong, S.H.; Tang, W.; Lukk, T.; Yu, Y.; Nair, S.K.; van der donk, W.A. The enterococcal cytolysin synthetase has an unanticipated lipid kinase fold. Elife 2015, 4. [CrossRef] [PubMed]

79. Gilmore, M.S.; Segarra, R.A.; Booth, M.C.; Bogie, C.P.; Hall, L.R.; Clewell, D.B. Genetic structure of the Enterococcus faecalis plasmid pAD1-encoded cytolytic toxin system and its relationship to lantibiotic determinants. J. Bacteriol. 1994, 176, 7335-7344. [CrossRef] [PubMed]

80. Willey, J.M.; van der Donk, W.A. Lantibiotics: Peptides of diverse structure and function. Annu. Rev. Microbiol. 2007, 61, 477-501. [CrossRef] [PubMed]

81. Tang, W.; van der Donk, W.A. The sequence of the enterococcal cytolysin imparts unusual lanthionine stereochemistry. Nat. Chem. Biol. 2013, 9, 157-159. [CrossRef] [PubMed]

82. Tang, W.; Jiménez-Osés, G.; Houk, K.N.; van der Donk, W.A. Substrate control in stereoselective lanthionine biosynthesis. Nat. Chem. 2015, 7, 57-64. [CrossRef] [PubMed]

83. Gilmore, M.S.; Segarra, R.A.; Booth, M.C. An HlyB-type function is required for expression of the Enterococcus faecalis hemolysin/bacteriocin. Infect. Immun. 1990, 58, 3914-3923. [PubMed]

84. Rumpel, S.; Razeto, A.; Pillar, C.M.; Vijayan, V.; Taylor, A.; Giller, K.; Gilmore, M.S.; Becker, S.; Zweckstetter, M. Structure and DNA-binding properties of the cytolysin regulator CylR2 from Enterococcus faecalis. EMBO J. 2004, 23, 3632-3642. [CrossRef] [PubMed]

85. Coburn, P.S.; Hancock, L.E.; Booth, M.C.; Gilmore, M.S. A novel means of self-protection, unrelated to toxin activation, confers immunity to the bactericidal effects of the Enterococcus faecalis cytolysin. Infect. Immun. 1999, 67, 3339-3347. [PubMed]

86. Brock, T.D.; Peacher, B.; Pierson, D. Survey of the bacteriocines of enterococci. J. Bacteriol. 1963, 86, $702-707$. [PubMed]

87. Stark, J.M. Antibiotic activity of haemolytic enterococci. Lancet 1960, 1, 733-734. [CrossRef]

88. Ryan, M.P.; Rea, M.C.; Hill, C.; Ross, R.P. An application in cheddar cheese manufacture for a strain of Lactococcus lactis producing a novel broad-spectrum bacteriocin, lacticin 3147. Appl. Environ. Microbiol. 1996, 62, 612-619. [PubMed]

89. Martin, N.I.; Sprules, T.; Carpenter, M.R.; Cotter, P.D.; Hill, C.; Ross, R.P.; Vederas, J.C. Structural characterization of lacticin 3147, a two-peptide lantibiotic with synergistic activity. Biochemistry 2004, 43, 3049-3056. [CrossRef] [PubMed]

90. Wiedemann, I.; Bottiger, T.; Bonelli, R.R.; Wiese, A.; Hagge, S.O.; Gutsmann, T.; Seydel, U.; Deegan, L.; Hill, C.; Ross, P.; et al. The mode of action of the lantibiotic lacticin 3147-A complex mechanism involving specific interaction of two peptides and the cell wall precursor lipid II. Mol. Microbiol. 2006, 61, 285-296. [CrossRef] [PubMed]

91. Jett, B.D.; Jensen, H.G.; Nordquist, R.E.; Gilmore, M.S. Contribution of the pAD1-encoded cytolysin to the severity of experimental Enterococcus faecalis endophthalmitis. Infect. Immun. 1992, 60, 2445-2452. [PubMed]

92. Ike, Y.; Hashimoto, H.; Clewell, D.B. Hemolysin of Streptococcus faecalis subspecies zymogenes contributes to virulence in mice. Infect. Immun. 1984, 45, 528-530. [PubMed]

93. Huycke, M.M.; Spiegel, C.A.; Gilmore, M.S. Bacteremia caused by hemolytic, high-level gentamicin-resistant Enterococcus faecalis. Antimicrob. Agents Chemother. 1991, 35, 1626-1634. [CrossRef] [PubMed]

94. Huycke, M.M.; Gilmore, M.S. Frequency of aggregation substance and cytolysin genes among enterococcal endocarditis isolates. Plasmid 1995, 34, 152-156. [CrossRef] [PubMed]

95. La Rosa, S.L.; Solheim, M.; Diep, D.B.; Nes, I.F.; Brede, D.A. Bioluminescence based biosensors for quantitative detection of enterococcal peptide-pheromone activity reveal inter-strain telesensing in vivo during polymicrobial systemic infection. Sci. Rep. 2015, 5, 8339. [CrossRef] [PubMed]

96. Schauder, S.; Shokat, K.; Surette, M.G.; Bassler, B.L. The LuxS family of bacterial autoinducers: Biosynthesis of a novel quorum-sensing signal molecule. Mol. Microbiol. 2001, 41, 463-476. [CrossRef] [PubMed]

97. Plummer, P.J. LuxS and quorum-sensing in Campylobacter. Front. Cell. Infect. Microbiol. 2012, 2, 22. [CrossRef] [PubMed]

98. Xavier, K.B.; Bassler, B.L. LuxS quorum sensing: More than just a numbers game. Curr. Opin. Microbiol. 2003, 6, 191-197. [CrossRef]

99. Chen, X.; Schauder, S.; Potier, N.; Van Dorsselaer, A.; Pelczer, I.; Bassler, B.L.; Hughson, F.M. Structural identification of a bacterial quorum-sensing signal containing boron. Nature 2002, 415, 545-549. [CrossRef] [PubMed] 
100. Pereira, C.S.; Thompson, J.A.; Xavier, K.B. AI-2-mediated signalling in bacteria. FEMS Microbiol. Rev. 2013, 37, 156-181. [CrossRef] [PubMed]

101. He, Z.; Liang, J.; Zhou, W.; Xie, Q.; Tang, Z.; Ma, R.; Huang, Z. Effect of the quorum-sensing luxS gene on biofilm formation by Enterococcus faecalis. Eur. J. Oral Sci. 2016, 124, 234-240. [CrossRef] [PubMed]

102. Winzer, K.; Hardie, K.R.; Burgess, N.; Doherty, N.; Kirke, D.; Holden, M.T. G.; Linforth, R.; Cornell, K.A.; Taylor, A.J.; Hill, P.J.; et al. LuxS: Its role in central metabolism and the in vitro synthesis of 4-hydroxy-5-methyl-3(2H)-furanone. Microbiology 2002, 148, 909-922. [CrossRef] [PubMed]

103. Trappetti, C.; Potter, A.J.; Paton, A.W.; Oggioni, M.R.; Paton, J.C. LuxS mediates iron-dependent biofilm formation, competence, and fratricide in Streptococcus pneumoniae. Infect. Immun. 2011, 79, 4550-4558. [CrossRef] [PubMed]

104. Scutera, S.; Zucca, M.; Savoia, D. Novel approaches for the design and discovery of quorum-sensing inhibitors. Expert Opin. Drug Discov. 2014, 9, 353-366. [CrossRef] [PubMed]

105. Sully, E.K.; Malachowa, N.; Elmore, B.O.; Alexander, S.M.; Femling, J.K.; Gray, B.M.; DeLeo, F.R.; Otto, M.; Cheung, A.L.; Edwards, B.S.; et al. Selective chemical inhibition of agr quorum sensing in Staphylococcus aureus promotes host defense with minimal impact on resistance. PLoS Pathog. 2014, 10. [CrossRef] [PubMed]

106. Desouky, S.E.; Nishiguchi, K.; Zendo, T.; Igarashi, Y.; Williams, P.; Sonomoto, K.; Nakayama, J. High-throughput screening of inhibitors targeting Agr/Fsr quorum sensing in Staphylococcus aureus and Enterococcus faecalis. Biosci. Biotechnol. Biochem. 2013, 77, 923-927. [CrossRef] [PubMed]

107. Singh, R.P.; Nakayama, J. Development of quorum-sensing inhibitors targeting the $f_{s} r$ system of Enterococcus faecalis. In Quorum Sensing vs Quorum Quenching: A Battle with No End in Sight; Kalia, V.C., Ed.; Springer: New Delhi, India, 2015; pp. 319-324.

108. Shojima, A.; Nakayama, J. Quorum sensing in gram-positive bacteria: Assay protocols for staphylococcal $a g r$ and enterococcal fsr systems. Methods Mol. Biol. 2014, 1147, 33-41. [PubMed]

109. Nakayama, J.; Tanaka, E.; Kariyama, R.; Nagata, K.; Nishiguchi, K.; Mitsuhata, R.; Uemura, Y.; Tanokura, M.; Kumon, H.; Sonomoto, K. Siamycin attenuates fsr quorum sensing mediated by a gelatinase biosynthesis-activating pheromone in Enterococcus faecalis. J. Bacteriol 2007, 189, 1358-1365. [CrossRef] [PubMed]

110. Ma, P.; Nishiguchi, K.; Yuille, H.M.; Davis, L.M.; Nakayama, J.; Phillips-Jones, M.K. Anti-HIV siamycin I directly inhibits autophosphorylation activity of the bacterial FsrC quorum sensor and other ATP-dependent enzyme activities. FEBS Lett. 2011, 585, 2660-2664. [CrossRef] [PubMed]

111. Li, Y.; Ducasse, R.; Zirah, S.; Blond, A.; Goulard, C.; Lescop, E.; Giraud, C.; Hartke, A.; Guittet, E.; Pernodet, J.L.; et al. Characterization of Sviceucin from Streptomyces Provides Insight into Enzyme Exchangeability and Disulfide Bond Formation in Lasso Peptides. ACS Chem. Biol. 2015, 10, 2641-2649. [CrossRef] [PubMed]

112. Nakayama, J.; Uemura, Y.; Nishiguchi, K.; Yoshimura, N.; Igarashi, Y.; Sonomoto, K. Ambuic acid inhibits the biosynthesis of cyclic peptide quormones in gram-positive bacteria. Antimicrob. Agents Chemother. 2009, 53, 580-586. [CrossRef] [PubMed]

113. Nakayama, J.; Yokohata, R.; Sato, M.; Suzuki, T.; Matsufuji, T.; Nishiguchi, K.; Kawai, T.; Yamanaka, Y.; Nagata, K.; Tanokura, M.; et al. Development of a peptide antagonist against $f s r$ quorum sensing of Enterococcus faecalis. ACS Chem. Biol. 2013, 8, 804-811. [CrossRef] [PubMed]

114. Desouky, S.E.; Shojima, A.; Singh, R.P.; Matsufuji, T.; Igarashi, Y.; Suzuki, T.; Yamagaki, T.; Okubo, K.I.; Ohtani, K.; Sonomoto, K.; et al. Cyclodepsipeptides produced by actinomycetes inhibit cyclic-peptide-mediated quorum sensing in Gram-positive bacteria. FEMS Microbiol. Lett. 2015, 362. [CrossRef] [PubMed]

115. Solheim, M.; La Rosa, S.L.; Mathisen, T.; Snipen, L.G.; Nes, I.F.; Brede, D.A. Transcriptomic and functional analysis of NaCl-induced stress in Enterococcus faecalis. PLoS ONE 2014, 9. [CrossRef] [PubMed]

116. Kristich, C.J.; Li, Y.H.; Cvitkovitch, D.G.; Dunny, G.M. Esp-Independent Biofilm Formation by Enterococcus faecalis. J. Bacteriol. 2004, 186, 154-163. [CrossRef] [PubMed]

117. Defoirdt, T.; Brackman, G.; Coenye, T. Quorum sensing inhibitors: How strong is the evidence? Trends Microbiol. 2013, 21, 619-624. [CrossRef] [PubMed] 
118. Gilmore, M.S.; Rauch, M.; Ramsey, M.M.; Himes, P.R.; Varahan, S.; Manson, J.M.; Lebreton, F.; Hancock, L.E. Pheromone killing of multidrug-resistant Enterococcus faecalis V583 by native commensal strains. Proc. Natl. Acad. Sci. USA 2015, 112, 7273-7278. [CrossRef] [PubMed]

119. Tan, S.Y.; Liu, Y.; Chua, S.L.; Vejborg, R.M.; Jakobsen, T.H.; Chew, S.C.; Li, Y.; Nielsen, T.E.; Tolker-Nielsen, T.; Yang, L.; et al. Comparative systems biology analysis to study the mode of action of the isothiocyanate compound Iberin on Pseudomonas aeruginosa. Antimicrob. Agents Chemother. 2014, 58, 6648-6659. [CrossRef] [PubMed]

120. Piras, C.; Soggiu, A.; Greco, V.; Martino, P.A.; Del Chierico, F.; Putignani, L.; Urbani, A.; Nally, J.E.; Bonizzi, L.; Roncada, P. Mechanisms of antibiotic resistance to enrofloxacin in uropathogenic Escherichia coli in dog. J. Proteom. 2015, 127, 365-376. [CrossRef] [PubMed]

121. Piras, C.; Soggiu, A.; Bonizzi, L.; Greco, V.; Ricchi, M.; Arrigoni, N.; Bassols, A.; Urbani, A.; Roncada, P. Identification of immunoreactive proteins of Mycobacterium avium subsp. paratuberculosis. Proteomics 2015, 15, 813-823. [CrossRef] [PubMed]

122. Nishiguchi, K.; Nagata, K.; Tanokura, M.; Sonomoto, K.; Nakayama, J. Structure-activity relationship of gelatinase biosynthesis-activating pheromone of Enterococcus faecalis. J. Bacteriol. 2009, 191, 641-650. [CrossRef] [PubMed]

(C) 2017 by the authors. Licensee MDPI, Basel, Switzerland. This article is an open access article distributed under the terms and conditions of the Creative Commons Attribution (CC BY) license (http:/ / creativecommons.org/licenses/by/4.0/). 